Bangladesh Journal of Neuroscience 2018; Vol. 34 (1): 39-44

\title{
Presence of Herpesviridae Genome in CSF of GBS Patients
}

\author{
RAHAMAN H ${ }^{1}$, RAHMAN HZ ${ }^{2}$, RANA MM ${ }^{3}$, ISLAM MR ${ }^{4}$, HANNAN MA ${ }^{5}$, KAWSAR MJ ${ }^{6}$ \\ REFAYET CNM ${ }^{7}$, HASAN $\mathrm{M}^{8}$, SARKER ${ }^{9}$, JANNAT $\mathrm{M}^{10}$, WAHIDUZZAMAN $\mathrm{M}^{11}$
}

\begin{abstract}
:
Background: Guillain Barre Syndrome (GBS) is considered as an immune mediated inflammatory disease of peripheral nerves and nerve roots. Herpes viruses like CMV, $E B V, H S V$ and VZV infections are associated with GBS. The aim of the study was to identify the presence and frequency of different Herpes virus genome by PCR assay in CSF of GBS patients Methods: An observational, cross sectional study was carried out in the Department of Neurology, BSMMU, and Dhaka. A total 50 (fifty) admitted GBS patients were included after fulfilling the inclusion and exclusion criteria. About $2 \mathrm{ml}$ of CSF was taken for detection of viral nucleic of CMV, EBV, HSV1, HSV2, VZV and HHV6 by Multiplex PCR method. Results: Herpesviridae genome in CSF of study population was present in 9 (18\%) patients. Maximum 3 (33.3\%) cases were HSV1, EBV and HSV2 found in 2 (22.2\%) patients, CMV and VZV in 1 (11.1\%) patient respectively. AMAN (66.6\%) was the most frequent electrophysiological pattern; followed by AIDP (33.3\%), mean CSF protein was (159 \pm 81$) \mathrm{mg} / \mathrm{dl}$ and mean cell count was $(2 \pm 3) / \mathrm{cmm}$ in these patients. Herpes virus genome positive group patients were more disabled and received definitive treatment more than the others. Conclusion: Herpesviridae genome was present in CSF of GBS especially in early collected CSF sample. Antiviral drugs might have a role in treating GBS patients having Herpes virus genome in CSF.
\end{abstract}

Key words: Guillain Barre Syndrome (GBS), Herpes Virus genome, PCR, CSF.

\section{Materials and methods:}

This cross sectional observational study. It was conducted in department of Neurology (In patient department), BSMMU, Dhaka. Male and female of 18 years or above who were diagnosed clinically by accepted clinical criteria as Guillain-Barre syndrome in inpatient department, department of Neurology, BSMMU, Dhaka was taken as study population. About 2-3 $\mathrm{ml}$ of CSF was taken for detection of PCR for viral nucleic acid of six virus of Herpesviridae group (CMV, EBV, HSV1, HSV2, VZV, and HHV6) by Multiplex PCR method (Seeplex meningitis ACE kit) in Microbiology department of BSMMU. Pattern of clinical presentationwas documented and disability was graded by Hughes functional grading scale. Routine CSF study was done in the Biochemistry and Clinical Pathology department for CSF protein and cytology respectively. Nerve conduction study was performed in the "Neurophysiology laboratory" of BSMMU and pattern of findings of these investigations were recorded. Presence and frequency of different Herpes virus genome was expressed in percentage and their association with variation in clinical presentation, electro-physiological findings and routine CSF findings was statistically analyzed by Chi-square test and t- test. The $P$ value $<0.05$ was considered statistically significant.

1. Dr. Habibur Rahaman, Phase-B resident, Department of Neurology, BSMMU, Dhaka, Bangladesh.

2. Prof. (Dr.) Hasan Zahidur Rahman, Professor, Department of Neurology, BSMMU, Dhaka, Bangladesh.

3. Dr. Md. Masud Rana, Assistant professor, Department of Neurology, BSMMU, Dhaka, Bangladesh.

4. Prof. (Dr.) Md. Rafiqul Islam, Professor \& Chairman, Department of Neurology, BSMMU, Dhaka, Bangladesh.

5. Prof. (Dr.) M. A. Hannan, Professor, Department of Neurology, BSMMU.

6. Dr. Md. Jafrul Kawsar, Phase-B resident, Department of Neurology, BSMMU, Dhaka, Bangladesh.

7. Dr. Chowdhury Neamul Hasan Refayet, Phase-B resident, Neurology, BSMMU, Dhaka, Bangladesh.

8. Dr. Mehedi Hasan, Phase-B resident, Department of Neurology, BSMMU, Dhaka, Bangladesh.

9. Dr. Imran Sarker, Registrar (Clinical Neurology), NINS\&H, Dhaka, Bangladesh.

10. Dr. Maftahul Jannat, Assistant Professor, Sirajul Islam Medical College, Dhaka, Bangladesh.

11. Dr. Md. Wahiduzzaman, Phase-B resident, department of Neurology, BSMMU, Dhaka, Bangladesh. 


\section{Results and observations:}

Table-I

Distribution of study population by age in relation to Herpesviridae genome in CSF $(n=50)$

\begin{tabular}{lcccc}
\hline Age in years & \multicolumn{3}{c}{ CSF viral genome by PCR } & P-Value \\
& $\begin{array}{c}\text { Absent } \\
\mathrm{n}(\%)\end{array}$ & $\begin{array}{c}\text { Present } \\
\mathrm{n}(\%)\end{array}$ & $\begin{array}{c}\text { Total } \\
\mathrm{n}(\%)\end{array}$ & \\
\hline$<20$ & $3(7.3)$ & $3(33.3)$ & $6(12)$ & $0.029^{\mathrm{s}}$ \\
$21-30$ & $13(31.7)$ & $4(44.4)$ & $17(34)$ & $0.465^{\mathrm{ns}}$ \\
$31-40$ & $9(22)$ & $0(0)$ & $9(18)$ & $0.120^{\mathrm{ns}}$ \\
$41-50$ & $6(14.6)$ & $0(0)$ & $6(12)$ & $0.221^{\mathrm{ns}}$ \\
$>50$ & $10(24.4)$ & $2(22.2)$ & $12(24)$ & $0.890^{\mathrm{ns}}$ \\
\hline Total & $41(100)$ & $9(100)$ & $50(100)$ & $0.098^{\mathrm{s}}$ \\
\hline
\end{tabular}
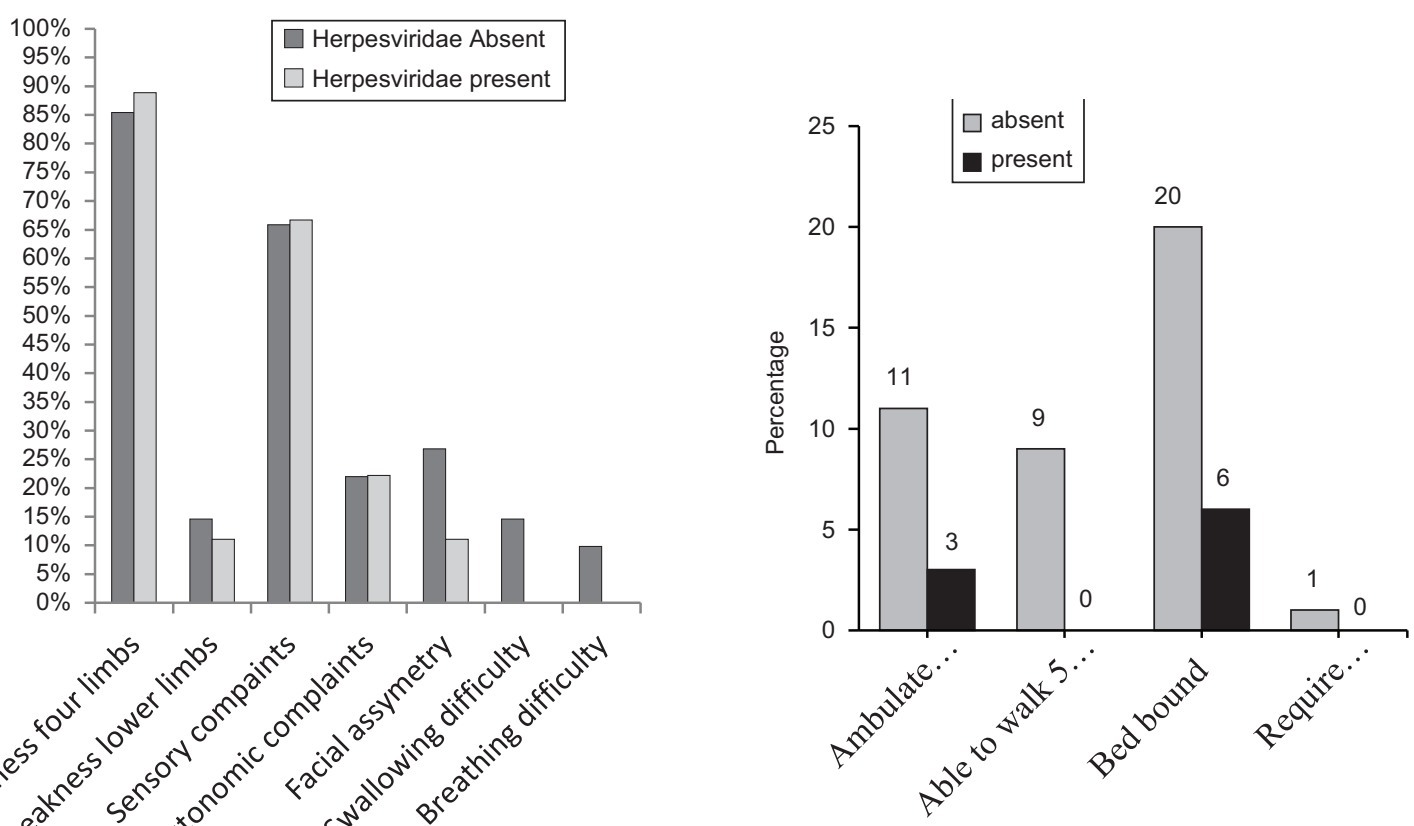

Fig.-1 (Bar diagram): Presenting complaints of study population.

Table-II

Presence of Herpesviridae genome in CSF of study population $(n=50)$

\begin{tabular}{lcc}
\hline Name of the Herpes virus & Number & Percentage \\
\hline CMV & 01 & 11.1 \\
EBV & 02 & 22.2 \\
HSV 1 & 03 & 33.3 \\
HSV 2 & 02 & 22.2 \\
VZV & 01 & 11.1 \\
HHV 6 & 00 & 0.00 \\
\hline Total & 09 & 100 \\
\hline
\end{tabular}

Fig.-2 (Bar diagram): Disability status of study population.

Table-III

CSF protein level of study population $(n=50)$

\begin{tabular}{|c|c|c|c|c|}
\hline & $\begin{array}{c}\text { Absent } \\
\text { Group } \\
\text { CSF protein } \\
\text { (mg/dl) }\end{array}$ & $\begin{array}{c}\text { Present } \\
\text { Group } \\
\text { CSF protein } \\
\text { (mg/dl) }\end{array}$ & Total & P-Value \\
\hline Mean & 178 & 159 & 175 & 0.774 \\
\hline $\begin{array}{l}\text { Standard } \\
\text { Deviation }\end{array}$ & 195 & 81 & 179 & \\
\hline
\end{tabular}


Table-IV:

CSF cytology of study population $(n=50)$

\begin{tabular}{ccccc}
\hline & $\begin{array}{c}\text { Absent } \\
\text { Group } \\
(\text { CSF } \\
\text { cell/cmm) }\end{array}$ & $\begin{array}{c}\text { Present } \\
\text { Group } \\
(\text { CSF } \\
\text { cell/cmm) }\end{array}$ & Total & P-Value \\
\hline Mean & 12 & 2 & 10 & 0.523 \\
Standard Deviation & 47 & 3 & 42 \\
\hline
\end{tabular}

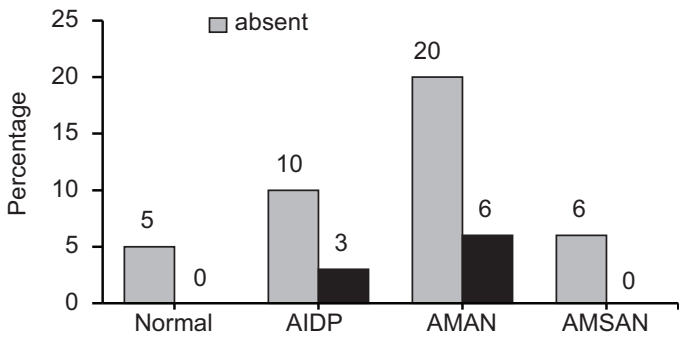

Fig.-3: (Bar diagram): Electrophysiological pattern of study population

Table-V

CSF collection time to detect Herpesviridae genome among cases at time interval in weeks $(n=50)$

\begin{tabular}{|c|c|c|c|c|}
\hline \multirow[t]{2}{*}{$\overline{\text { CSF collection time }}$} & \multicolumn{2}{|c|}{ CSF viral genome by PCR } & \multirow[b]{2}{*}{$\begin{array}{l}\text { Total } \\
\mathrm{n}(\%)\end{array}$} & \multirow[b]{2}{*}{ P-Value } \\
\hline & $\begin{array}{l}\text { Absent } \\
\mathrm{n}(\%)\end{array}$ & $\begin{array}{c}\text { Present } \\
\mathrm{n}(\%)\end{array}$ & & \\
\hline$<7$ days & $0(0)$ & $1(11.1)$ & $1(2)$ & $0.031^{\mathrm{s}}$ \\
\hline 8-14 days & $22(53.7)$ & $7(77.8)$ & $29(58)$ & $0.184^{n s}$ \\
\hline 15-28 days & $19(46.3)$ & 1(11.1) & $20(40)$ & $0.050^{\mathrm{ns}}$ \\
\hline$\overline{\text { Total }}$ & $41(100)$ & $9(100)$ & $50(100)$ & $0.023^{s}$ \\
\hline
\end{tabular}

Table-VI

Distribution of study population by received treatment $(n=50)$

\begin{tabular}{lcccc}
\hline Treatment modalities & \multicolumn{2}{c}{ CSF viral PCR positivity } & & \\
\cline { 2 - 4 } & Absent & Present & Total & P-Value \\
& $\mathrm{n}(\%)$ & $\mathrm{n}(\%)$ & $3(\%)$ & \\
\hline Conservative & $29(70.7)$ & $4(44.4)$ & $33(66)$ & $0.131^{\mathrm{ns}}$ \\
Plasma exchange & $9(22)$ & $5(55.6)$ & $14(28)$ & $0.042^{\mathrm{s}}$ \\
IVIG & $3(7.3)$ & $0(0)$ & $3(6)$ & $0.402^{\mathrm{ns}}$ \\
\hline Total & $41(100)$ & $9(100)$ & $50(100)$ & $0.110^{\mathrm{ns}}$ \\
\hline
\end{tabular}

\section{Discussion:}

Guillain-Barre Syndrome (GBS) is considered as an immune mediated inflammatory disease of peripheral nerves and nerve roots. Two thirds of patient has a preceding history of various viral and bacterial infections before the symptoms onset ${ }^{1}$. GBS is thought to be result of immune reaction against these infectious agents having epitope similar to peripheral nerves myelin sheath or axonal membrane component. This type of molecular mimicry was found mainly those of bacterial infectious agent like Campylobacter jejuni, Hemophylus influenzae and Mycoplasma. Herpes viruses like CMV, EBV, HSV and VZV infections are associated with $\mathrm{GBS}^{3}$. The above mentioned mechanism of nerve injury cannot be proved in virus associated GBS patients who may have different pathogenesis described in some study.

Different study shows that antibody against herpes virus and PCR for herpes virus genome was found in serum and CSF of GBS patients. As their study found PCR for Herpes virus genome was present in CSF of GBS patients after disease onset so they claimed that there may be ongoing infection or presence of Herpes virus genome in CSF has a different role in GBS pathogenesis. This cross- 
sectional observational study was carried out primarily with an aim to identify the presence of different Herpes virus genome by multiplex PCR method in CSF of GBS patients, to identify their frequency, any association with variation in clinical presentation, electrophysiological pattern and routine CSF findings of them. A total 50 (fifty) GBS patients admitted in the Neurology department of BSMMU, Dhaka, were included after fulfilling the inclusion and exclusion criteria. GBS patients of any age and sex were included in our study.

We have made two groups on the basis of presence or absence Herpes virus genome in CSF of GBS patients within 4 weeks of disease onset. We have also compared between two groups to find out any association of CSF Herpes virus genome positivity with any variation in pattern of clinical presentation, electrophysiological findings, cytological and biochemical parameter of CSF. The timing of presence of Herpes virus genome by multiplex PCR method in CSF of GBS patients and its significance was also observed.

Analysis of age distribution (Table-I) of two groups showed that the mean age $( \pm S D)$ was $39( \pm 15)$ years in CSF Herpes virus genome absent group and $30( \pm 16)$ years in CSF Herpes virus genome present group. Male patients were $42(84 \%)$ and female patients were $8(16 \%)$. Higher frequency was found in male than female. Most of the study patients were young adults of 21-30 yrs, 4 (44.4\%) patients in CSF Herpes virus genome positive group and $13(31.7 \%)$ patients in CSF Herpes virus genome negative group. So our study showed that Herpes virus genome in CSF is found in younger GBS patients. In this study presenting complaints (Figure-1, Bar diagram) was weakness of all four limbs in $43(86 \%)$ patients, lower limb weakness in $7(14 \%)$ patients. Sensory complaints were present in $33(66 \%)$ of patients. Complaints of facial weakness or deviation were present in $12(24 \%)$ patients, $4(8 \%)$ patient had breathing difficulty and $6(12 \%)$ patients had dysphagia. There was no significant difference found in terms of clinical presentation in between two groups. In our study maximum number of patients $20(48.8 \%)$ were in the grade 4 disability scale in Herpes virus genome absent group and $6(66.7 \%)$ patients were in
Herpes virus genome present group. Patients who had Herpes virus genome in CSF were more disabled during admission than who had absent Herpes virus genome in CSF (Figure-II). Our study found Herpes virus genome in CSF was present in $9(18 \%)$ patients and was absent in $41(82 \%)$ patients. Maximum 3 (33.3\%) cases were HSV1 followed by $2(22.2 \%)$ cases were EBV and HSV2, $1(11.1 \%)$ was CMV and VZV respectively (TableII). This result has similarity with that of Armin S. et al., $(2014)^{13}$ who found Herpes virus genome in CSF of GBS patients in $20 \%$ cases (3 out of 15 patients).

In our study CSF was drawn between 8-14 days of disease onset in maximum $22(53.7 \%)$ patients followed by 19 (46.3\%) patients within 15-28 days in CSF Herpes virus genome negative group. In contrast CSF was drawn between 8-14 days of disease onset $7(77.8 \%)$ patients and $1(11.1 \%)$ patient within 7 days in CSF Herpes virus genome positive group. So our study found that Herpesviridae genome was found more in GBS patients whose CSF was taken early after disease onset (Table-V). Our one specific objective was to find out any correlation between two groups in regards of CSF findings. Mean protein was $(178 \pm 195) \mathrm{mg} / \mathrm{dl}$ in Herpes virus genome absent group and $(159 \pm 81) \mathrm{mg} / \mathrm{dl}$ in Herpes virus genome present group respectively. Mean cell count was $(12 \pm 47) / \mathrm{cmm}$ in Herpes virus genome absent group and $(2 \pm 3) / \mathrm{cmm}$ in Herpes virus genome present group respectively (Table-III). No significant difference was found between two groups but CSF cell count and protein was higher in Herpesviridae genome negative group (Table-IV).

We also had a specific objective to see association of presence of Herpes virus genome in CSF with electrophysiological pattern of our patients. The present study found predominant electrophysiological subtype in both group was AMAN found in $6(66.7 \%)$ patients in Herpes virus genome positive group and $20(48.8 \%)$ patients in CSF Herpes virus genome negative group. Next common electrophysiological pattern was AIDP observed in $3(33.3 \%)$ patients in CSF Herpes virus genome positive group and $10(24.4 \%)$ patients in CSF Herpes virus genome negative group 
respectively. NCS was normal in $5(12 \%)$ patients (Figure-III). No significant association was found between presence of Herpes virus genome in CSF and electrophysiological pattern. But axonal variants (AMAN and AMSAN) constitute the predominant subtype $64 \%$ (52\% AMAN and 12\% AMSAN) in our population. A study done by Islam et al. $(2010)^{7}$ in Bangladesh, also found higher frequency of axonal variants in 67\% (AMAN-56\% and AMSAN-11\%) followed by AIDP in $22 \%$ of cases and $11 \%$ were unclassified. Thus the present study has similarities with the previous study although AIDP was the predominant subtype in many developed countries including Europe and North America. Another observation of our study is presence of CSF Herpes virus genome render the patient to receive more specific treatment than who has absent Herpes virus genome in CSF. Definitive treatment was given more in CSF Herpes virus genome positive group (55.6\%) patients than CSF Herpes virus genome negative group (49.3\%) patients. Fourteen (14, 28\%) patients were treated with plasma exchange and $3(6 \%)$ patient received intravenous immunoglobulin during their course of illness. Majority 33 (66\%) of patients had received conservative treatment (Table-VI).

\section{Conclusion:}

The present study showed that Herpesviridae genome may be found in CSF of GBS patients after the disease onset especially in younger patients. The presence of Herpes virus genome by PCR assay in CSF of GBS patients early in the disease course carries significance. It may be related with ongoing or current infection or a different pathogenesis may coexist in these GBS patients but actual mechanism of Herpesviridae genome presence in CSF yet to be elucidated. Present study also showed that Herpes virus genome positivity was associated with greater disability of the GBS patients and necessitated specific costly treatment more than the other patients. But present study failed to correlate the presence of Herpesviridae genome in CSF of GBS patients with routine CSF findings and with the electrophysiological pattern. As our study showed that early in the disease course of GBS patients Herpesviridae genome is present in CSF, so whether antiviral drug can be effective or not in these patients is a matter of debate and demand for further study

\section{References:}

1. Vucic S, Kiernan MC, Cornblath DR. GuillainBarré syndrome: an update. Journal of clinical neuroscience. 2009 Jun 1;16(6):733-41.

2. van Doorn PA, Ruts L, Jacobs BC. Clinical features, pathogenesis, and treatment of Guillain-Barré syndrome. The Lancet Neurology. 2008 Oct 1;7(10):939-50.

3. Bashar K., Disorders of Peripheral Nerves, Neurology in clinical practice, $7^{\text {th }}$ edition, 2016, pp.1818-27.

4. Visser LH, Van der Meché FG, Meulstee J, Rothbarth P, Jacobs BC, Schmitz PI, Van Doorn PA. Cytomegalovirus infection and Guillain-Barré syndrome: the clinical, electrophysiologic, and prognostic features. Neurology. 1996 Sep 1;47(3):668-73.

5. Govoni V, Granieri E. Epidemiology of the Guillain-Barré syndrome. Current opinion in neurology. 2001 Oct 1;14(5):605-13.

6. Hadden RD, Karch H, Hartung HP, Zielasek J, Weissbrich B, Schubert J, Weishaupt A, Cornblath DR, Swan AV, Hughes RA, Toyka $\mathrm{KV}$. Preceding infections, immune factors, and outcome in Guillain-Barré syndrome. Neurology. 2001 Mar 27;56(6):758-65.

7. Islam Z, Jacobs BC, Van Belkum A, Mohammad QD, Islam MB, Herbrink P, Diorditsa S, Luby SP, Talukder KA, Endtz HP. Axonal variant of Guillain-Barre syndrome associated with Campylobacter infection in Bangladesh. Neurology. 2010 Feb 16;74(7):581-7.

8. Jacobs $\mathrm{BC}$, Rothbarth $\mathrm{PH}$, Van der Meché FG, Herbrink P, Schmitz PI, De Klerk MA, Van Doorn PA. The spectrum of antecedent infections in Guillain-Barré syndrome: a casecontrol study. Neurology. 1998 Oct 1;51(4):1110-5.

9. Rabinstein AA.. Guillain-Barré Syndrome. Open General Internal Medicine Journal. 2007, 1:13-22. 
10. Kuijf ML, Ang CW, van Doorn PA, Niesters HG, Jacobs BC. Presence or absence of cytomegalovirus in cerebrospinal fluid from patients with Guillain-Barre syndrome?. The Journal of infectious diseases. 2006 May 15;193(10):1471-2.

11. Drenthen J, Yuki N, Meulstee J, Maathuis EM, van Doorn PA, Visser GH, Blok JH, Jacobs BC. Guillain-Barré syndrome subtypes related to Campylobacter infection. Journal of Neurology, Neurosurgery \& Psychiatry. 2011 Mar 1;82(3):300-5.

12. Steininger C., Popow-Kraupp T., Seiser A., Gueler N., Stanek G. and Puchhammer E.. Presence of cytomegalovirus in cerebrospinal fluid of patients with Guillain-Barre syndrome.
The Journal of infectious diseases. 2004, 189(6):984-89.

13. Armin S, Shamsabadi FM, Kiomarci A, Jadali F. Virologic Evidences of Active Herpesviridae Infection in Children With Guillain-Barre Syndrome. Archives of Pediatric Infectious Diseases. 2014;2(1):169-73.

14. Asbury AK, Cornblath DR. Assessment of current diagnostic criteria for Guillain Barré syndrome. Annals of Neurology: Official Journal of the American Neurological Association and the Child Neurology Society. 1990;27(S1):S21-4.

15. Uncini A, Kuwabara S. Electrodiagnostic criteria for Guillain-Barré syndrome: a critical revision and the need for an update. Clinical neurophysiology. 2012 Aug 1;123(8):1487-95. 